\title{
Folk Art and Fine Art from the Puerto Rican Diaspora: Individuation, Cultural Preservation, and Resistance
}

\author{
Erika Land
}

\begin{abstract}
Puerto Ricans in north Philadelphia experience marginalization in the larger culture, but also incorporation into the multiple ethnicities that have historically made up Puerto Rican identity. Both of these experiences are reflected in the art of Taller Puertorriqueño, an arts education program for children and youth in the area. Taller permits social and cultural mobility as well as freedom of artistic expression by constantly pushing boundaries, allowing students to represent more authentic reflections of their values as a means of dealing with cultural ambiguity. In addition, they rewrite their oppressive history by leveraging human and cultural values embedded in their artistic language. Taller is a mission-oriented institution that uses art for social transformation in the community and for celebrating a fluid ethnic and social identity. Though not a religious institution, Taller's art reflects the religious commitments of the Puerto Rican community, enacts the liturgy of art in ways that contribute to God's transformative kingdom, and thereby helps to promote good stewardship throughout the community.
\end{abstract}

Puerto Ricans of North Philadelphia challenge the cultural stereotypes and dead-end expectations for many Latino-Americans in the U.S. by expressing themselves through art. Art is a co-creative expression of being human and of what it is to suffer, and is used to transform unfavorable circumstances into those of social action and empowerment. Most of all, art is a cultural expression that helps communicate social unrest and social solidarity. Taller Puertorriqueño (Taller), a cultural arts center in the heart of the barrio, exploits the tension between beauty and pain by pushing the boundaries between folk art and fine art, opening up space and bringing attention to social issues and expectations of Latinos in North Philadelphia, permitting more authentic reflections of their values embedded in the artistic language of the community. As they attempt to rewrite their sometimes oppressive history, Latinos' art can be seen as a part of their struggle toward self-realization and, thus, a move toward reconciliation with God.

In 1917, the U.S. Congress declared all Puerto Ricans U.S. Citizens, while labor recruitment increased migration and began to define the formation of Puerto Rican communities (Whalen and Vazquez-Hernandez 2005: 1). Puerto Ricans migrated to different states in the U.S., but most established large communities throughout New York City (NYC) and Philadelphia, defining new cultural territory and expanding large bilingual neighborhoods such as in New York, where many Puerto Ricans self-identified as Nuyoricans. This brought about a rich explosion of the arts in NYC such as poetry and street art, and also resulted in the $5^{\text {th }}$ Street corridor in North Philadelphia from which Taller Puertorriqueño emerged as el corazón cultural del barrio (the "cultural heart of the neighborhood"). A modest program that serves not only adults, but young artists in an after-school program, Taller engages young Latino students at risk due to a consistent current of racial-profiling combined with a lack of equal access to economic and educational resources.

Taller operates as a way to address cultural barriers as well as establish a network of local artists within the thriving community. It diffuses and addresses current social issues through a multi-modal approach and provides opportunities of expression that cross geographical boundaries. In the past, Taller has been focused on local art mediums and cultural concepts in and around Latino culture. More recently, the Taller community has expanded their cause to include cultural arts studies from the Puerto Rican diaspora, offering opportunities for students to reach past their local arts community, giving them a larger community in which to exercise their ability to articulate their vision.

This more open dialogue with the world gives artists in this community a chance to preserve their own culture while holding a dialogue with the art world at 
large. It also forces audiences to consider the mixture of themes and mediums that are represented as an authentic reflection of Puerto Ricans and the larger Latino culture. This strategy is used as a way to counter limited expectations and stereotypes about adolescents and young adults in Latino North Philadelphia and allows them to blur the lines, offering them a way to leverage the tension found between beauty and pain by re-writing their history.

\section{Puerto Rican Identity and Boundary Pushing}

After first visiting the galleries at Taller, I met with the Executive Director, Carla Fuentes.' As someone who has been there from the beginning, Carla was able to tell me what it was like in the 1970's when Taller was started. She said, "Back then, the reason why Taller was started was out of need. Puerto Rican's did not have a voice and this was a way for them to be heard and to make their mark." Many older Latina women I have talked to remember this time and they remember that Puerto Ricans were not welcomed. The irony of this rejection was that Puerto Ricans had been pushed and persuaded to come to the mainland, enticed with jobs that promised a better life (Whalen and VazquezHernandez 2005: 37). Carla said, "Back in those days, 95\% of the people in that area were Puerto Rican and now it is about $65 \%$." Even though the ethnicity of the population is changing, she gave me the sense of shared cultural circumstances, explaining how Puerto Ricans experience some of the same social problems as other minorities, such as being racially profiled and pulled over by the police.

As we continued to discuss art and the artwork produced at Taller, I asked Carla how Taller was able to progress forward into the greater art community, while still holding to the traditions of Puerto Rican heritage (keeping certain principles can confine, rather than liberate you as an artist). This dynamic is a main focus of Taller-to embrace cultural arts in a way that explores Latin heritage but also strives toward a multicultural presence, exceeding expectations that may be dictated by certain stylistic choices. Carla commented, "Culture is always changing and that is one of the main principles of Taller from the beginning. Pushing work so that people will listen...Taller changes its direction based on the changes in the community." This fine balance, this tension between tradition and change, was a means of developing the arts for Taller.

Our conversation shifted to the relevance of language in the arts. Students in this community don't often have art programming that is relevant to them in their schools because the programming does not include Latinos, their language, or their history in the curriculum. Practicing culturally and linguistically responsive pedagogy is well-known in multi-cultural education practices. But it has been a topic of much controversy, and it is seldom actually practiced in the public education system. To address this need, Taller has a portfolio development component of their program and it is bilingual-English and Spanish. Furthermore, Carla stated that, "Taller gives students a stronger sense of self" due to the fact that they can express themselves artistically beyond the limits of language. Verbal and written expression has its limits, and is sometimes unable to encompass a student's unique background, whereas nonverbal artistic expression may have fewer translation challenges.

I asked Carla about the relationship between beauty in art and personal hardship or the pain of human suffering-tragedy, loss, sorrow, mental illness, fear, or total selflessness. She said that "Creativity is the window to a person, it is truth, it is real-it is honest." As an artist myself, I can attest that when you get to the point in your artwork in which expressing or articulating your experiences is one of the things that reminds you that there is hope, that you are alive, it can actually be painful if you don't create. Thus, beauty and pain are linked in the art that is produced at Taller, at both the individual and community levels.

A few days later, when I stopped by the arts center, I met with Abril Santiago, the Director of Education. Abril showed me what the students had been working on. For the summer, the focus of their Project Based Learning was on African Roots. Many people don't know that Puerto Ricans have an African heritage. In fact, many Puerto Ricans don't identify with this history either, though they are aware of being Native American (Taino Indian), as well as Spanish. Yet Puerto Ricans are always proud of being "boricua", a mixed race, similar to Brazilians, Cubans, Colombians, and other Latin Americans.

Taller is very focused on the push and pull of the Puerto Rican cultural heritage. They want to preserve what it is to be Puerto Rican, while also reaching out to develop a deeper connection to the rich heritage that is the natural diaspora of Puerto Ricans. With this philosophy, this mission, Taller Puertorriqueño has an open heart toward other Latinos in the community and welcomes students of all Latino backgrounds. It intentionally brings up the question of what it means to be Puerto Rican as part of the balance, the tension, over cultural identities and the binary between beauty and pain. In order to explore African roots, Abril found a professional stilt walker to work with the students. They built stilts out of scrap wood and designed cord necklaces from the Kente tribe of southern Ghana. Then the students wore the necklaces in a performance

'Though I have used Taller Puertorriqueño's actual name in this article, all informants are given pseudonyms. 
that combined African, Taino Indian, and Spanish dancing.

Figure 1: Student Performance with Stilts

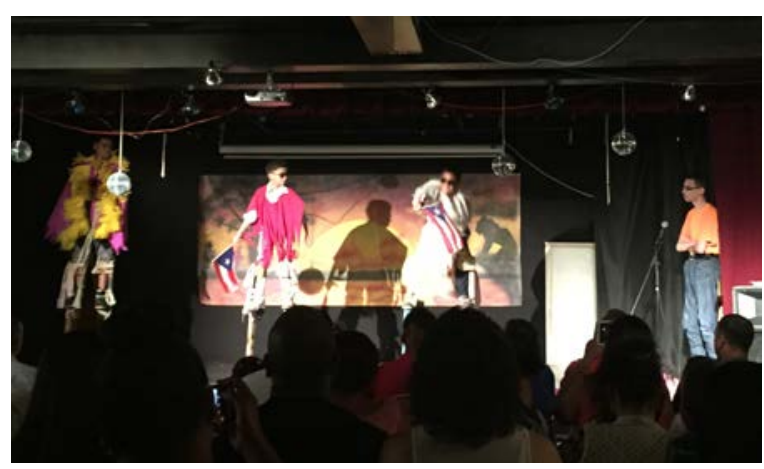

Taller has been a pioneer of change, and an example contesting a long history of elitism in the art world as well as an oppressive history. Abril explained how this came to be for Taller and why it was important to change the system of art-making as well as who gets to call it fine art. She elaborated on the beginnings of the program:

Taller started in the basement of ASPIRA [an organization of charter schools for Hispanic children in the area] with community people that wanted to make printmaking and teach it to others. With this ideal, Taller has opened the door to many artists that don't have a "highly reputable education" to come and show their art next to well-known artists. Taller is part of the community and that means that we welcome all artists to be part of our exhibits.

The model Taller uses is heuristic and mirrors what the original Taller was about in the basement of the building so many years ago, helping students to discover things for themselves and giving them the tools to do so. Students are not only learning aspects of their cultural heritage and other cultures but they are using them in performance, giving them a fixed meaning in temporal form. For instance, Abril told me that the students have been learning to play the drums and sing in a traditional Bomba y Plena Afro-Latino style of music. African drums have been carried across many cultures such as in Afro-Cuban music and Afro-Brazilian music.

Abril talked about the stilt-walking teacher and how she had used an analogy with the students about what it means to be physically high up, to be able to look down at everyone. She said that it symbolizes confidence, a metaphor that works both aesthetically and kinesthetically. Further, there is also an analogy here between the asymmetrical relationships in art and in power structures, particularly in racially disempowered social institutions. Abril went on to say that when you are high and looking over everyone you can choose to come down to relate to people in a more practical way. Fittingly, the focus for their upcoming project was super-heroes, when students would study Latino leaders, pioneers, and revolutionaries as super-heroes, and recognize themselves as superheroes in the process.

\section{Fluidity and Fusion in the Arts}

The cultural fluidity and fusion between African, Taino Indian, and Spanish identities that is felt all over the island of Puerto Rico through the music, in the food, and in the work of local artists produces new ideas and forms in art. It is very much the same at Taller Puertorriqueño where the location nestled in the $5^{\text {th }}$ street corridor and immediate surrounding area serves as a living narrative for the people of their vibrant and changing culture. At Taller's spring festival, the cultural fusion was clearly seen in the main display room, shifting between visual 2D arts such as paintings, prints and drawings, which are more visceral and inward, and the contrasting performative and 3D art, each leveraging off of the other. Individual works were unique, yet together created a somewhat haphazard installation as a whole. Installation art is very popular now because it incorporates a role for the audience/viewer. It creates a secondary form of art, apart from the artists' own work, because it requires participation of the audience and includes the viewer experience as part of the work. The display at Taller for their spring festival was daring-forcing the viewer to digest many thoughts, impressions, concepts, media and images all at once-while being a part of the exhibition.

One can see the mixed and culturally fused identity of Taller Puertorriqueño and Puerto Ricans as a people, an ethnic group and a community, in the creative energy displayed in different works of art. Bomba y Plena music is a great example of this. Although these two types of Puerto Rican folk music are stylistically different, they are associated with one another and often played together. Plena music began about 100 years ago in Puerto Rico and has been traditionally used as a platform to express daily life such as events, news, messages, even to protest. ${ }^{2}$ Plena music follows a call and response model of artistic expression and uses pandeiro hand drums that are of different sizes. Bomba music is a musical dialogue between the dancer and the drummer (traditionally). Bomba has African drums that are played simultaneously with the

${ }^{2}$ www.prfdance.org. Accessed on April 1, 2017. 
dancer dictating the percussion, the rhythms, and the conversation of the music.

When these two styles are fused together, something beautiful happens. This fusion is something we will see again and again. The tradition of skirtdancing provides the gesture for the drummer's queues. Ladies wearing colorful skirts make gestures with their skirts along with rhythmic movements. Typical Bomba has just one dancer, but when mixed with the elements of Plena, there are multiple dancers coordinating movements together. Bomba y Plena then becomes a shared exchange between the drummers and the dancers interacting with one another through gesture. I asked Abril, Taller's Educational Director to tell me about this and she explained,

When the dancer goes up to the drummer she/he politely asks to have a duel between the two. These duels come with a lot of respect and honor. The dancer will conduct the dance steps and the drummer will try to follow by pounding the drums resembling what she/he is dancing. At the end, she/he will salute him/her with the skirt or hat in a way of saying thank, you have my respect.

\section{Themes of Cultural Identity}

Bomba $y$ Plena is also shared by the Taller community in and around many of their events. They are both traditional forms and yet each of the styles is distinct. Because one of the performers will dictate the performance to a degree, and every performer and performance is different, the results are unpredictable. I wanted to understand how this reciprocity, this creative dialogue, took shape in the Taller community and how it related to other bodies of work at Taller. Abril told me:

Well, the community that is here misses the island and [they] want to connect back to their roots. Taller provides that. We have events that may not be the same to the one in the island but we can see the community coming to visit and feeling more at home. And like every dance, at the end the community respects us and salutes us on our accomplishments and what we have done for the community.

You can see the larger reflection of the Bomba $y$ Plena tradition in how the events are carried out at Taller. I asked Abril how the call and response method of communicating with the audience changes art. Abril said that, "As for the call and response they keep coming back as would the dancer. Taller would be the drummer by responding to the needs and the urge the community has of having a piece of the island here in
Philadelphia." The longing for Puerto Rico, but the embracing of new ties with other Latinos in Philadelphia, are both expressed. This tension is constantly felt, sometimes it is beautiful and sometimes painful. Abril says, "Art has many ways to be interpreted, in a way depending on where you come from and who you are. Art has different meanings. The artist may have their own meaning when creating a piece, but I think it is the audience that gives the real meaning of the work of art." Therefore, in this situation, the audience is the community, not just the Taller community, but the community of Centro de Ouro (Gold Center) and the Philadelphia community at large, with a special long distance "shout out" to Puerto Rico. It reinforces the pride that Boricuas have in themselves and their island no matter where they are.

This is not to say that the Latino community at Taller only includes Boricuas (natives to the island), rather it is the nature and history of the Puerto Rican people to include all Latinos as themselves. This political disposition can be traced back to Pedro Albizu Campos, a nationalist, political prisoner of the US government, and the most well-known pioneer of Puerto Rico's history (Denis 2015: 9, 11). His presence is still strongly felt in Puerto Rican culture and art. Many of the trigger-points of injustice that Campos fought for are still being contested today.

Even now Puerto Ricans are still fighting the political and cultural colonialization that has marked their entire history. In relations with the U.S. government, they have been put in a position that inhibits any successful outcome of independence movements due to problems with corruption, severe debt, and deprivation. Their economy is heavily based on manufacturing and tourism, with international trade that does not benefit Puerto Ricans themselves. Recent legislation such as PROMESA, The Puerto Rico Oversight, Management, and Economic Stability Act, is masked as an initiative to help Puerto Rico's economy grow, but is in fact about restructuring debt to serve outside interests. An activist group in Philadelphia-the Philadelphia Camden Boricua Committee-protests that the critical level of debt found in Puerto Rico was created by the U.S. and that Puerto Rico has not been able to "exercise autonomy to solve its economic problems" leaving natives of Puerto Rico "no alternative but to migrate. "The U.S. and its corporations benefit from this colonial relation," they state, as "for more than a century [they have] kept the island in bondage as a colony of the U.S." (Gamboa 2015).

Most of the debt Puerto Rico owes bond holders are in hedge funds, also known as "vulture funds," which specialize in high risk assets, and the debt has changed hands so many times that it has been hard to track as it is bought and sold on Wall Street. Worst of 
all, bondholders are selling the debt to high profile investors with exceptionally high nets worth, yielding the irony that the generally very poor Puerto Rican people owe large amounts of money to very rich Americans (ibid.). This system of exploitation plays into the artistic expression of cultural identity that is found at Taller.

\section{Communicative Systems of Beauty \& Pain}

\section{Religious Symbols}

The connection between the arts, humanities, and religion has been evolving for a long time in the Puerto Rican community in Philadelphia. During the inter-war period, between WWI and WWII, there was an economic transformation in the city that led to gentrification, prompted by post-industrial conditions, and leading many Puerto Ricans to relocate in northern Philadelphia (Whalen and Vazquez-Hernandez 2005: 91-2).

Religion is integral to Puerto Ricans living on the island. Religious icons are displayed on storefronts, sold in local drug stores, and accessible road-side depending where you are. Preservation of religion and faith was critical for Puerto Ricans for social survival when they first began to migrate to the U.S. One of the most important churches during the development of the panLatino community in Philadelphia was La Milagrosa, serving as a platform for charity work, mutual aid relationships, and eventually the arts. The latter enabled Puerto Ricans and other Latinos to build community and use the arts as a social strategy, preserving their culture in a segregated Philadelphia (ibid.). The strength of La Milagrosa's congregation led to many other organizations that served the greater need of the "Pan-Latino Colonia," to provide a religious basis for Puerto Rican family and community needs. Taller is an example of such an organization. Though Taller does not have a religious affiliation, I asked Abril, "Do you think religion is an important part of heritage in the States and do you see it in the artwork at Taller?" She explained:

Religion is very important in Puerto Rico. Especially if you grow up on the island-trust me on that. As part of our heritage it's really important personally, I have a collection of wood carving saints [talla de santos] which resemble the Catholic traditions of having a saint in the house. In today's society, the saint is more of a collector's item with no religious meaning, but you can still see how the religious influence is very strong in the arts. When it comes to Taller artists you can see some of them have a religious icon that touches on the religious iconography of the island.

\section{Cultural Symbols}

It was emphasized that many of the goals of the Project Based Learning approach at Taller had a component of cross-cultural fusion as well. Abril showed me a project that was inspired by the pinata, originally from Mexico, but that used a process and medium coming from China. The students combined the idea of the pinata with masks used in a well-known cultural festival in Puerto Rico. It was a sort of crosscultural fusion represented in paper-mache art. They used elements of design from traditional vejigante masks that can be found in every gift shop and art gallery in Puerto Rico during the Ponce Festival-masks that are an icon of folklore on the island. The vejigante masks are wildly colorful, sometimes with patterned faces, and always with horns and spikes all over them. Students used the paper-mache process to construct the multiple horns, transforming each piece into a brightly colored sphere-shaped pinata. Visually the masks were very strange, and at the same time interesting.

There are other cultural symbols used by the students at Taller. Abril spoke about the ones that come up most frequently. She said,

The artists that exhibit in Taller use the hibiscus flower [Flor de Maga] which is the Puerto Rican state flower, the coqui [a small Puerto Rican frog], machetes [big knives to cut grass], the flag, Pedro Albizu Campos [the nationalist hero], the jibarito [a traditional fried green plantain sandwich]. I can keep going on but those are the ones that are more recurrent in the artists that show their work in Taller.

Figure 2: Student Self-Portrait Collages

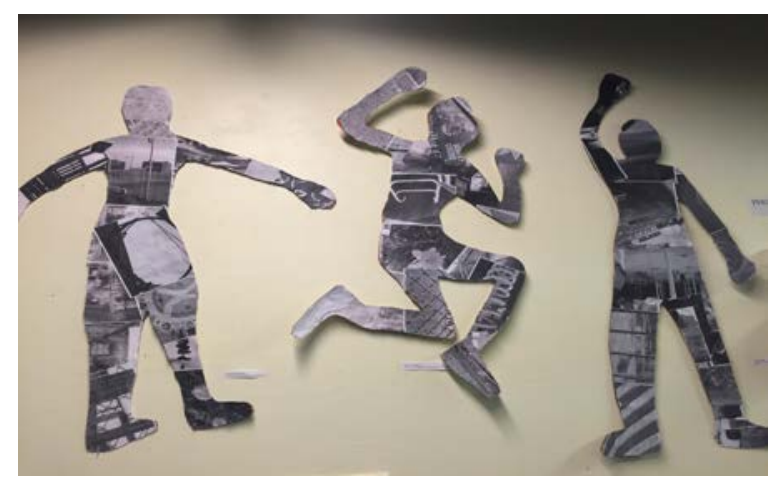

One of the students used the jibarito as a symbol in a life size self-portrait collage. He cut out a silhouette of himself, and collaged in the jibarito in place of his head. I found this to be very metaphorical. The purpose of the work was for the artists to represent themselves with whatever images they chose for the collage. On the one 
hand, he had plantains, a trademark of many Latin kitchens, and on the other hand a sandwich, translating as mass-consumption and very American. From an artistic perspective, it seemed that he had represented himself more as a commodity than as a person.

Abril described the symbolism of the machete in Latin American art. The machete is an icon of emancipation and survival for Afro-Brazilians (who also consider themselves Afro-Latinos) because of the frequent use in labor during the slave trade. It can also be viewed in some Latin American countries as a source of protection and empowerment. The machete is traditionally seen in a folk dance called Maculele, using long wooden sticks as a stand-in and partnering up in a sort of line dance with a call and response scenario-with partners smacking the sticks together at points throughout the dance and dictated by the music.

The living narrative that I have observed, that I have been a part of, at Taller, has demonstrated many things I have sought to understand, uncover and explain. The community operates and thrives as a living installation. Installation art is a type of art-making and process that utilizes the installation of different mediums and objects in or throughout a certain space, and the way that they are integrated composes the work. As explained earlier, this is intended to involve the experience of the viewer or audience through multiple means of perception. Installation art is closely associated with the DADA movement of socially-engaged and participatory art. Thus, the Taller Puertorriqueño community functions as a living installation in the Centro de Ouro district of North Philly. Taller is constantly pushing the boundaries and exploiting the tension between beauty and pain by playing with communicative systems held through themes, signs, and symbols within their community.

\section{Borders and Liminality: An Anthropological Analysis}

Taller Puertorriqueño is able to move freely between ethnic categories and uses art to amplify this fluidity and this ability to shift. It permits social and cultural mobility as well as freedom of artistic expression, assisting and bringing attention to social issues and expectations of Latinos in North Philadelphia. The tension that is exhibited throughout the community in regard to boundary maintenance is necessary in order to open up space, reliving and reassigning their history through art.

Anthropologist, Mary Douglas, discusses the idea of contagion within a society that has social boundaries defended by the concept of dirt and defilement, or pollution (Douglas 2002: 160). People who occupy such boundary positions are in a state of liminality. Taller is a community that has persistently responded to liminality by embracing it through the history of gentrification of its neighborhood. Although Taller has been pushed to the edges of visible public boundaries, the community pushes right back and plays with this tension, utilizing their cultural ambiguity in a way that is triumphant-just like the dancer and the drummer. Douglas discusses how "dirt" which is usually destructive, can become creative (ibid.). In this case, Taller is using tension and continuity by allowing cultural ambiguity to be the vehicle for its success. Douglas notes that, "So long as identity is absent, rubbish is not dangerous" (ibid.). Taller has become proficient in making artistic space for social advancement through self-realization and selfproclamation. Thus, Taller is able to exploit the cultural categories in which society has placed Puerto Ricans through art within their community.

Taller uses a culturally fused identity that shifts, changes, and is completely fluid. Bomba y Plena music is a great example of this kind of shifting. Through it Taller plays with the boundaries, and invites liminality in, allowing interaction between these two styles despite the distinct traditions. The result is a shared exchange and a moving installation with roots that can be traced in multiple directions.

Abril, the Director of Education at Taller, had said that just as the dancer returns to the drummer in Bomba $y$ Plena, the community keeps coming back to Taller. The metaphor is of the call and response, reflecting Taller's service to the community by addressing its boundaries and its liminal status. Like Bomba y Plena, Taller is communal, not just performative.

Douglas asserts that at this stage, in which they have some sense of identity, people in liminal circumstances are perceived as the most dangerous. Their half-identity still clings to them, but the larger social scene is impaired by their presence (2002: 161). In fact, liminal status can be very painful because of the lack of acceptance in either category. Sometimes the response to this pain takes the form of irony. Taller promotes the use of irony, humor, and sarcasm to push back on the liminal status and subjugation of the community.

Brazilian social theorist Paulo Freire, who asserts that dialogue is a better pedagogy than the usual "deposit and consume" process of education, says that the naming of the world is an important form of learning and acting (Freire 1970: 88-91). Taller circumvents the oppressive stereotyped images of themselves that Puerto Ricans receive in streets and schools by encouraging student artists to name themselves and the world. By so doing, it provides a critical lens to address the oppressed/oppressor relationship and the injustice of marginal status (ibid., 52). 
In Freire's liberationist pedagogy, positive change comes in two stages: 1) the oppressed acknowledge their world of oppression and commit to transform it; and 2) transformation takes place as pedagogy is owned by the people themselves in a process of ongoing liberation (ibid., 54). Taller is not only naming, but also transforming the world of their community. Freire claims that poverty and oppression can cause people to be trapped in a culture of silence. He says that, "The masses are mute, that is, they are prohibited from creatively taking part in the transformation of their society and therefore prohibited from being. Even if they can occasionally read and write because they were 'taught' in humanitarian - but not humanist - literacy campaigns, they are nevertheless alienated from the power responsible for their silence" (Freire 1985: 50). Taller is breaking the silence through art for the many Puerto Rican young people that come there to express their culture, their community, and their identity. It does this in part by flipping the tables of oppression, creating a "dirt to fashion" or "trash to treasure" aesthetic, again turning disadvantage into advantage. The materials that are the oppressor's refuse (donated materials and scraps of wood and fabric)-that they discard-become the items that Taller uses to create art, fueling a thriving art culture in their own community.

\section{Art as Liturgy: A Theological Analysis}

Because of its unique mission to educate its members and help to re-write their history through the arts, Taller Puertorriqueño does not make a clear distinction between fine art and folk art. Rather Taller's art crosses over the boundary and is accessible to all. Nicholas Wolterstorff distinguishes between three types of art: high art (for the elite), popular art (for ordinary people), and the "art of the tribe" (for the whole group) (Wolterstorff 1980: 21-23). He states that, as an example, our liturgical art still belongs to our art of the tribe because it is accessed by both elite and non-elite alike. But most of our "art of the tribe" today is produced by commercial establishments, as the marketplace has replaced the church as primary producer of art (ibid., 23-24). Taller's uniqueness lies in the fact that it cannot be tagged as fine art or folk art, nor has it been commercialized-yet it remains authentic and rich. Further, the everyday work of the people within the Taller community represents a liturgical practice in the sense of J.K.A. Smith (2009). We all have formative habits that represent our liturgical practice as a process of moving toward God's kingdom and flourishing, says Smith. Our habits and rituals, such as in art and the process of creating itespecially in a communal context-is representative of our desire for the kingdom.

Land, Folk Art and Fine Art from the Puerto Rican Diaspora
Because God created the human being, we have capacities of rationality, freedom and dignity that are intrinsic to us, that we can use to participate in the transformation of the world into the kingdom, particularly when we are influenced by our faith and by Jesus (Hall 1986: 44). God expects us to participate in this transformation as stewards who care for the world and for each other. Ephesians 2:10 says, "For we are God's handiwork, created in Christ Jesus to do good works, which God prepared in advance for us to do" (NIV). A large part of the philosophy behind Taller is rooted in faith and doing good for one another, so as to be a community of good stewards.

Yet art does not only reflect our goodness; it also reflects human evil. Wolterstorff explains the connection between art and the fallenness of our nature (Wolterstorff 1980: 84). When discussing art in historical context, Wolterstorff reminds us of the price that has sometimes been paid, "The art that you and I now admire in the scrubbed stillness of the museum once dripped with blood, reeked of idolatry, or caused its makers suicidal depression and anguish” (ibid.). Just as art has the ability to communicate refinement, balance, unity, justice and harmony, it may also communicate dissonance, irregularity, disparity and chaos. The full human experience is reflected in art.

Max Stackhouse applies the concepts, theoria, praxis, and poesis, to theological education in ways that are helpful to understanding how Taller is able to encourage stewardship (Stackhouse 1988: 84). Praxis is a way of knowing, living and being in the world, or the action/reflection mode of teaching and learning. At Taller people live, work and create in a constant state of tension-this is what drives them forward, to push the boundaries within the community and carry them out into the world. Stackhouse notes that "Poesis involves imaginative creation or representation of evocative images" and this includes discovery through aesthetic and kinesthetic experience (ibid., 85). Taller uses both aesthetic and kinesthetic approaches to teach students. This helps them to develop a stronger sense of self and a more comprehensive cultural critique. Theoria has to do with observation, interpretation and critical evaluation. Members of the Taller artist community use the arts as a form of cultural critique and a way to look at something anew by reframing it and reinventing it. When applying these three concepts to Taller as a living installation in the community, poesis takes a front seat and theoria and praxis are secondary but critical elements of Taller's mission and purpose.

Taller has an undergirding of faith-based practices and religious sentiment even though as a cultural arts center, it is, strictly speaking, a secular establishment. Taller promotes creation care by re-purposing and reinventing as well as caring for one another in the community and being conscious of community 
resources. This is because the community lives with liminal status in the greater Philadelphia area and uses its cultural arts center as a critical discourse through aesthetics-a platform for reconciliation with themselves, each other, and God.

\section{Conclusion}

Arts have preserved culture through human relationships and set the stage for human testimony of what our lives mean and how they are valued. Art brings cohesion to cultures that are put to the test through migration, assimilation, language barriers and economic oppression.

Taller Puertorriqueño stays committed to preserving Puerto Rican heritage while confronting assigned cultural categories and stereotypes through aesthetic response; encompasses and includes other Latino cultural groups in its community; and encourages culture fusion through the arts for the purpose of creating a positive identity. Taller erases the distinction between fine art and folk art by using themes and mediums that reflect the Latino community in North Philadelphia, and thereby creates art that resists the hegemony of the larger culture in the manner of Freire's liberation pedagogy. In the end, our human aesthetic response-to beauty through our senses-is an aspect of full self-realization. It is an element of our reconciliation with God and with one another, hinting at the ultimate plan for us for glory in His Kingdom.

\section{Bibliography}

Clifford, James and George E. Marcus. 1986. Writing Culture: The Poetics and Politics of Ethnography. Berkley: University of California Press.

Denis, Nelson A. 2015. War Against All Puerto Ricans: Revolution and Terror in America's Colony. New York: Nation Books.

Douglas, Mary. 2002. Purity and Danger: An Analysis of Concepts of Pollution and Taboo. New York: Routledge.

Freire, Paulo. 1970. Pedagogy of the Oppressed. New York: Bloomsbury Publishing, Inc.

— 1985. The Politics of Education: Culture, Power, and Liberation. Westport, CT: Bergin \& Garvey Publishers.

Gamboa, Ana. 2015. "Al Dia Newsbites: Boricuas demand accountability from U.S. Government.” http://aldianews.com/articles/local/philadelphia/boricuas -demand-accountab. Accessed, April 1, 2017.

Hall, Douglas John. 1986. Imaging God: Dominion as Stewardship. Eugene, OR: Wipf and Stock Publishers.

Isasi-Diaz, Ada Maria and Fernando F. Segovia. 1996. Hispanic/Latino Theology: Challenge and Promise. Minneapolis: Augsburg Fortress Publishers.

McFague, Sallie. 1982. Metaphorical Theology: Models of God in Religious Language. Philadelphia: Fortress Press.
Smith, James K.A. 2009. Desiring the Kingdom: Worship, Worldview, and Cultural Formation. Grand Rapids: Baker Academic.

Smith, Christian. 1991. The Emergence of Liberation Theology: Radical Religion and Social Movement Theory. Chicago: The University of Chicago Press.

Stackhouse, Max L. 1988. Apologia: Contextualization, Globalization, and Mission in Theological Education. Grand Rapids: William B. Eerdmans Publishing Co.

Whalen, Carmen Teresa and Victor Vazquez-Hernandez. 2005. The Puerto Rican Diaspora: Historical Perspectives. Philadelphia, PA: Temple University Press.

Wolterstorff, Nicholas. 1980. Art in Action: Toward a Christian Aesthetic. Grand Rapids: Eerdmans Publishing Company.

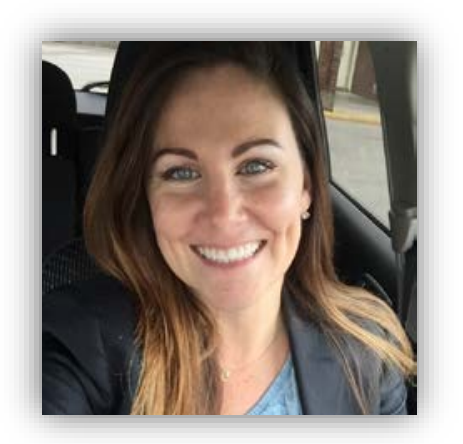

Erika Land is an alum of the MA in Theological and Cultural Anthropology at Eastern University. She has research interests in art as ethnography and is a member of the Society for Latin American and Caribbean Anthropology (SLACA).

Author email: landerika@yahoo.com 